\title{
The Mediating Impact of Occupational Stress on Leadership Style and Job
} Performance

\author{
Nor Azimah Chew Abdullaha ${ }^{a^{*}}$, Thilakavathi Balakrishnan ${ }^{b}$ \\ aSchool of Business Management, Universiti Utara Malaysia (UUM), Sintok, Kedah, Malaysia \\ ${ }^{b}$ Tenaga Nasional Berhad, Bandar Perda, Bukit Mertajam, Pulau Pinang \\ *Corresponding author: norazimah@uum.edu.my
}

\begin{abstract}
The aim of this study is to evaluate the intervening effect of occupational stress on leadership style and job performance. Using a proportionate stratified random sampling, questionnaire survey was employed and distributed to the employees of utility industries in Malaysia and a total of 175 employees participated. The regression results showed that: (1) it is partially supported for a significant association between leadership style and job performance, (2) it is partially supported for a significant association between leadership style and occupational stress. Contrary to expectation, there have no intervening effect of occupational stress on the association between leadership style and job performance. One probable explanation could be that the occupational stress level itself was found low among respondents. Respondents highlighted they have the work-related stress but perhaps due to most of them are healthy, educated, lack in working experience, or due to they are yuppies, (that is indicating they are in young age, ambitious, and hunger for challenging tasks), they did not perceive the stress as the actual stress as felt by the other group of age. Thus, the result suggested that occupational stress as an intervening role among the yuppies group is not a relevant issue in discussing job performance. In future study, other factors should be considered to increase about the explanation on job performance.
\end{abstract}

Keywords: Leadership style, occupational stress, job performance

(C) 2016 Penerbit UTM Press. All rights reserved

\subsection{INTRODUCTION}

The statistic in the EU15 (European Union) found that occupational stress is the second most common problem of health (28\%) and back pain which was frequently highly reported (Houtman, 2007). The dramatic change in the workplace has given impact on women employee, older and high educated employee along with increased migration (Houtman, 2007; Kompier, 2002; Landsbergis, 2003; National Institute for Occupational Safety and Health, 2002). Therefore, there is the urgency of understanding the role of occupational stress in enhancing the job performance at work.

The problem of occupational stress may affect the performance of the employees at work. Researchers found that stress has an impact to the employees, organizations and society and it has become a major significant concern to public health (Martinez \& Fischer, 2009). Consistently, previous literature has highlighted that failure in handling occupational stress affects human health (Limm et al., 2011) and thus, de-motivates the employees at work, specifically on their job performance. The observed occupational stress, however, is not known to what extent and the actual sources of it.

The occupational stress however is also a leadership challenge for the organization. Despite occupational stress derived from many ways, the way leaders behaved during the interaction process of delivering work task is crucial to minimize the stress level (Bhatti, Shar, M.Shaikh, \& Nazar, 2010). It appears that there is abundant literature connecting to the leadership styles with organizational culture. Leadership is vital as the characteristics of leadership styles are known able to affect performance at work (Yukl, 2008; Yun, Cox, Henry P. Sims, \& Salam, 2007). Therefore, this study is conducted to evaluate the intervening effect of occupational stress on leadership style and job performance.

\subsection{LITERATURE REVIEW}

Leadership is defined as a specific traits, roles, and other reasons that one person has (Betts et al., 2008). According to Bhatti et al. (2010), bad leadership has the potential to create stress among the employees. Research indicated that different leadership style has different impact at organizational and individual level (Lee \& Chuang, 2003; Taleb, 2010). Transformational leadership style has a different focus and influence in motivating the followers to perform in comparison to transactional leadership style. A leader with transformational style or transformational leader is involved in motivating their employees to achieve transcendental and longer-term goals, and is referred as "changing agents" (Betts et al., 2008; McShane \& Glinow, 2010). Conversely, Betts et al. (2008) described a transactional leader as a person who gives autonomy for employee to solve the problem. In this type of leadership, the leader is reaching the objectives of the 
organization by improving employee performance and satisfaction, which is referred as "managing" or "doing things right" (McShane \& Glinow, 2010). A study by Lee and Chuang (2003) was done in insurance industry in Taiwan that found the impact of leadership on work stress and intention to leave. Their findings found the significance influence of leadership style on work stress and the work stress have positively associated with turnover intention (Lee \& Chuang, 2003). Researchers concluded that different leadership style has different impact on work willingness, but they did not provide details on this issue.

Performance in terms of task and citizenship were predicted from the joint effects of personality and social exchange relationships in workplace (Kamdar \& Dyne, 2007). From 230 employees of both co-workers and their supervisors, Kamdar and Dyne's (2007) findings supported that social exchange relationships moderates the effects of personality on work and citizenship performance. Kamdar and Dyne's (2007), and Motowidlo et al. (1997) defined job performance as behavior that transforms the inputs into outputs produced by the organization and acts as maintenance in assuring efficient functioning of the organization. Study of McNamara et al. (2011), Yahaya et al. (2009) and Fries (2009) found stress has significant health impact, but their discussion on their findings was vague. In addition, the present study has found many researchers who surveyed occupational stress as mediator, but dominant studies were on job satisfaction such as Halkos and Bousinakis (2010), Chen and Silverthorne (2008), and Yahaya et al. (2009).

Based on the above scenario, the hypotheses are:

\section{H1: There is a significant association between leadership style and job performance}

i. H1 (a): There is a positive association between democratic leadership style and job performance.

ii. H1 (b): There is a negative association between autocratic leadership style and job performance.

iii. H1(c): There is a positive association between Laisezz Faire and job performance.

\section{H2: There is a significant association between leadership style and occupational stress}

i. H2 (a): There is a positive association between democratic leadership style and occupational stress.

ii. H2 (b): There is a negative association between autocratic leadership style and occupational stress.

iii. H2(c): There is a negative association between Laizezz Faire leadership style and occupational stress.

\section{H3: There is a significant positive association between occupational stress and job performance.}

\section{H4: Occupational stress intervenes the association between leadership style and job performance}

i. H4 (a): Occupational stress intervenes the association between democratic leadership style and job performance

ii. H4 (b): Occupational stress intervenes the association between autocratic leadership style and job performance

iii. H4(c): Occupational stress intervenes the association between Laisezz Faire and job performance

\subsection{METHODOLOGY}

A total of 175 employees in utility industries participated in this study, representing a response rate of 55.21\%. However, the actual usable data was $53.94 \%$ (171). The data was gathered through questionnaire using proportionate stratified random sampling. The leadership styles questionnaire was adopted from the 17-item of leadership measures in the study of Kassim and Sulaiman (2011) and a five-point Likert scale was used, where (1) strongly disagree to (5) strongly agree. As for occupational stress scale, the questionnaire was adopted from Chen et al. (2009) and a six-point Likert scale was used, where (1) no stress at all to (6) very stressful. Measurement for job performance was adopted from Rousseau and Aube (2010), by using five-point Likert scale ranging from (1) very low and (5) very high. Analysis of data was done using Statistical Package for Social Science (SPSS) version 19.0, Pearson correlation and regression analysis were used in this study.

\subsection{FINDINGS}

\section{Demographic Profile}

A majority of respondents were youngsters aged between $21-30$ years (57.9\%). Males were dominant respondents (66.7\%) and $42.7 \%$ from the total respondents were married with no kids. However, the profiling also showed that the percentage of single respondents who participated in this study was $40.4 \%$. More than half of the respondents had tertiary education $(61.2 \%)$ and $44.1 \%$ of them were employed within 2-4 years. The profile also recorded that non-executive staff was the majority $(52.0 \%)$ and more than $90 \%$ were not on shift-work basis $(92.3 \%)$. Most of the respondents had their overtime work between 1-30 hours (66.7\%). In terms of their health status, $62.8 \%$ had their medical leave between 1-10 days and the profile also shows that about $66 \%$ never smoke in their life (65.9\%) and majority of them has no sleeping problems $(61.9 \%)$. 


\section{Reliability Analysis}

Table 1 illustrates Cronbanch's Alpha for the instrument. The reliability for dependent variable (job performance) consisting of 5 items was 0.927 . This result is more than 0.6 at the range of excellent and considered as having high reliability and can be accepted in this study. For independent variables; leadership style with three dimensions; (1) democratic style consists of 11 items with Cronbanch's Alpha of $0.930,(2)$ autocratic style comprises of 5 items with Cronbanch's Alpha of 0.806 , (3) laisezz faire contains 2 items with reliability coefficient of 0.854 . Whereas, occupational stress (mediating variable) consists of 8 items with Cronbanch's Alpha of 0.921 . This results can be accepted because it is greater than 0.6 (Sekaran, 2003).

Table 1 Reliability coefficients for the major variables

\begin{tabular}{|c|c|c|}
\hline Independent variable & No. of items & $\begin{array}{c}\text { Cronbach } \\
\text { Alpha }\end{array}$ \\
\hline \begin{tabular}{ll}
\multicolumn{2}{l}{ Leadership style } \\
- & Democratic style \\
- & Autocratic style \\
- & Laisezz faire
\end{tabular} & $\begin{array}{c}11 \\
5 \\
2\end{array}$ & $\begin{array}{l}.930 \\
.806 \\
.854\end{array}$ \\
\hline $\begin{array}{l}\text { Mediating variable } \\
\text { Occupational stress }\end{array}$ & 8 & .921 \\
\hline $\begin{array}{l}\text { Dependent variable } \\
\text { Job performance }\end{array}$ & 5 & .927 \\
\hline
\end{tabular}

\section{Hypothesis Testing}

\section{i. $\quad$ Correlation among variables}

The Pearson product-moment correlation coefficients (r) were computed to examine the correlations and directions among the study variables in determining the interdependency of the study variables. As illustrated in Table 2, the dimensions of democratic and liaises faire leadership style were correlated positively with job performance. While the dimension of autocratic leadership style was correlated negatively with job performance. The results showed that if respondents have better leadership style, they tend to have better job performance. However, the mediator variable (occupational stress) was not significantly correlated with the dimension of leadership style and neither with job performance.

Table 2 Correlation between variables

\begin{tabular}{|c|c|c|c|c|c|c|}
\hline & Variables & 1 & 2 & 3 & 4 & 5 \\
\hline 1 & Democratic & - & & & & \\
\hline 2 & Autocratic & -.124 & - & & & \\
\hline 3 & Laisezz Faire & $.481 * *$ & -.039 & - & & \\
\hline 4 & Occupational Stress & .123 & -.047 & -.095 & - & \\
\hline 5 & Job performance & $.390 * *$ & $-.181 *$ & $.177 *$ & .099 & - \\
\hline
\end{tabular}

\section{ii. $\quad$ The Intervening Effect of Occupational Stress on Leadership Style and Job performance}

The hierarchical regression analyses were carried out to examine independent variable (leadership style) and dependent variable (job performance) in the model. The approach of Baron and Kenny (1986) was used as shown in Figure 1. Specifically, hypothesis H4 posits that occupational stress intervenes the relationship between leadership styles and job performance.

Table 3 shows the direct relationship between leadership styles and job performance. The result of regression analysis between the leadership styles and job performance showed partial association. It can be concluded that only democratic and autocratic leadership style were supported while liaises faire leadership style was not accepted. As for the results of leadership styles and occupational stress showed partial association and it can be concluded that only democratic and liaises faire leadership style were supported while autocratic leadership style was not accepted. Lastly, the result of association between occupational stress and job performance showed that occupational stress was not significantly related to job performance. 
To examine hypothesis H4, hierarchical regression analysis was not carried out due to Baron and Kenny's (1986) step 3 not producing significant association between occupational stress and job performance. Therefore, the results of correlation analysis is referred and utilised accordingly.

Figure 1 shows the mediation model of Baron and Kenny (1986). It explains that:

Equation 1: $\beta 1$ must be significant (IV must influence DV significantly)

Equation 2: $\beta 2$ must be significant (IV must influence mediator significantly)

Equation 3: $\beta 3$ must be significant (mediator must influence DV significantly)

Equation 4: If $\beta 4$ is not significant, $\mathrm{Y}$ is fully mediated, if $\beta 4$ is significant, $\mathrm{Y}$ is partially mediated.

Table 3 Regression analysis: leadership style and job performance

\begin{tabular}{lll}
\hline Dependent Variable & \multicolumn{1}{c}{ Independent Variables } & Beta \\
\hline Job performance & Leadership Style: & $.378^{* * *}$ \\
& $\bullet \quad$ Democratic style & $-.133^{*}$ \\
& $\bullet \quad$ Autocratic style & -.011 \\
\hline & R2 Laisezz faire & .170 \\
& Adjusted R2 & .155 \\
& R2 Change & .170 \\
& F Change & 11.313 \\
\hline Occupational stress & Leadership Style: & \\
& $\bullet \quad$ Democratic style & $.215^{* *}$ \\
& $\bullet \quad$ Autocratic style & -.028 \\
& $\bullet \quad$ Laisezz faire & $-.200^{* *}$ \\
\hline & R2 Adjusted R2 & .047 \\
& R2 Change & .030 \\
& F Change & .047 \\
Job performance & Occupational Stress & 2.714 \\
\hline & R2 & .099 \\
\hline & Adjusted R2 & .010 \\
& $\mathrm{R} 2$ Change & .004 \\
& F Change & .010 \\
\hline
\end{tabular}

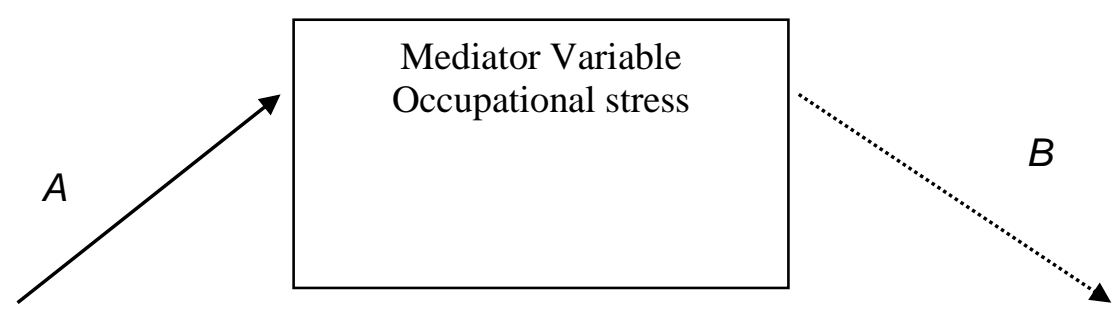

\begin{tabular}{c} 
Independent Variable \\
Leadership Style \\
\hline
\end{tabular}

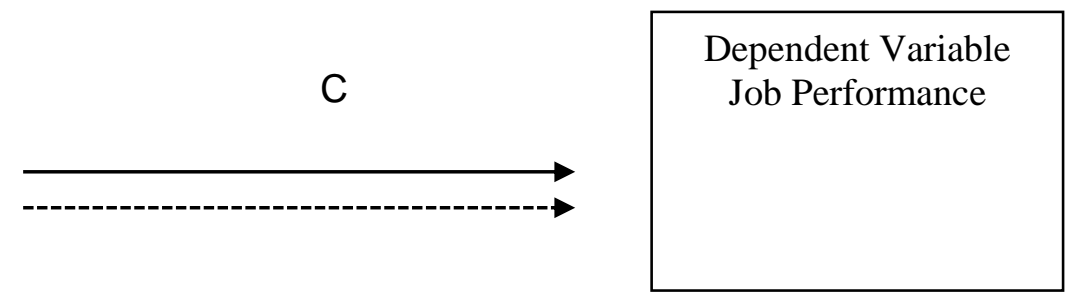

Figure 1 Mediation Model: Baron \& Kenny (1986) 


\subsection{DISCUSSION AND CONCLUSION}

This study found three identified leadership styles were practiced but only two namely democratic and autocratic were significantly related with job performance. The democratic leadership style was positively related and the autocratic style was negatively related to the job performance. Democratic $(\beta=.378, \mathrm{p}<.001)$ was found to be the strongest or most preferred leadership style which predicted the job performance that was measured by achieving goals, productivity, work quality, cost respect, and deadline respect. The second strongest leadership style was autocratic $(\beta=-.133, p<.05)$. The results implied that the more democratic and the lesser of autocratic leadership styles have been practiced, the better job performance. More in practicing democratic or the lesser practicing of autocratic are found most significant because the characteristic of the leadership offer the most effective guidance, encourage more participation and allow inputs from the employees. The employees tend to engage more, feel motivated and creative. The findings support previous research notation of

$\mathrm{Wu}$ et al.'s (2007) that good relationship between leaders and subordinates would influence the followers to achieve the organizational goals. The evidence was also supported by the research done by Stashevsky and Koslowsky (2006) that the leadership capability has enable on the enhancing performance of the organization.

This study found that democratic and Laisezz Faire were significantly related to occupational stress. The democratic was positively related to occupational stress $(\beta=.215, \mathrm{p}<.01)$ and Laisezz Faire was negatively related to occupational stress $(\beta=.200, \mathrm{p}<.01)$. As highlighted, the finding results showed that the more the leaders shared the problems with the employees, the more employees coped with the occupational stress. The negative association between Laisezz Faire leadership style and occupational stress shows that when the leaders chose to avoid giving least guidance or pay more attention or control in their leadership capabilities, the better the employees control their stress at work. When the Laisezz Faire was negatively hypothesized, it indicated that the leader must lead and avoid the "freerein" style. The leaders must not allow maximum freedom to their staff or subordinates in the decision making process in reducing the stress level felt by the employees. The findings support the past research of Channuwong (2009) that leadership dimension would be able to determine good performance.

Contrary to expectation, the association between occupational stress and job performance was not supported. One probable explanation could be that the occupational stress level itself was found low among respondents. Respondents highlighted they have the work-related stress but perhaps due to most of them are healthy, educated, lack in working experience, or due to they are yuppies, (that is indicating they are in young age, ambitious, and hunger for challenging tasks), they did not perceive the stress as the actual stress as felt by the other group of age. This finding is similar to Oke and Dawson (2008) study which found the stressors varies according to these demographics profile. However, it is observed that the dominant participants in this study were from the male group, occupying almost $70 \%$ of total respondents. In the study of Schuldt and Totten (2008), their findings indicated that the stress level was experienced most by female who had similar nature of work of 24/7. Therefore, it can be speculated that by gender wise frustration and stress did not significantly appear to revolve in the workplace. Further, similar findings of Chen and Silverthorne (2008) and Elstad and Vabo (2008) also revealed that about $80 \%$ of female workers experienced a negative effect on her / their performance. In short, empirically the occupational stress associated with the health impact evidenced among the female employees.

However, the occupational stress was partially related to independent variable, but was not related to job performance. Thus, the result suggested that occupational stress as a mediating role among the group is not a relevant issue in discussing job performance. Special attention should be given to more experienced employees working for more than five years (Oke \& Dawson, 2008).

The findings show the scenario of leadership style, occupational stress, and job performance in selected utility industries in Malaysia. Although the department was identified as mostly undergoing occupational stress levels, future study should cover a wider scope of industries in Malaysia. Wider scope may give different result compares to this study. In addition, in overall leadership styles, they have explained of $17 \%$ of the impact on job performance. The result indirectly explained that there are other $83 \%$ of unexplained contributing factors towards job performance. In future study, other factors should be considered to increase the explanation on job performance.

\section{References}

Baron, R. M., \& Kenny, D. A. (1986). The Moderator-Mediator Variable Distinction In Social Psychological Research: Conceptual, Strategic, And Statistical Consideration. Journal of Personality and Social Psychology, 51, 1173-1182.

Betts, S. C., Morgan, W., \& Castiglia, B. (2008). Who's A Leader? Students' Implicit Theories Of Leadership. Paper Presented At the Allied Academies International Conference, Tunica.

Bhatti, N., Shar, A. H., M.Shaikh, F., \& Nazar, M. S. (2010). Causes Of Stress In Organization, A Case Study of Sukkur. International Journal of Business and Management, 5(11), 3-7.

Channuwong, S. (2009). Strategies For Reducing Stress Among Managers: An Integrated Physical And Spiritual Approach. International Journal of Management, 26(2), 334-341.

Chen, J.-C., \& Silverthorne, C. (2008). The Impact Of Locus Of Control On Job Stress, Job Performance And Job Satisfaction In Taiwan. Leadership \& Organization, 29(7), 572-582

Chen, W.-Q., Wong, T.-W., \& Yu, T.-S. (2009). Influence Of Occupational Stress On Mental Health Among Chinese Off-Shore Oil Workers. Scandinavian Journal of Public Health, 37, 766-773.

Elstad, J. I., \& Vabo, M. (2008). Job stress, Sickness Absence And Sickness Presenteeism In Nordic Elderly Care. Scandinavian Journal of Public Health, 36, 467474.

Fries, M. (2009). Mindfulness Based Stress Reduction For The Changing Work Environment. Journal of Academic and Business Ethics, 2, 1-10.

Hair, J. F., Black, W. C., Babin, B. J., Anderson, R. E., \& Tatham, R. L. (2010). Multivariate Data Analysis (6th. ed.): Prentice Hall International Inc.

Halkos, G., \& Bousinakis, D. (2010). The Effect Of Stress And Satisfaction On Productivity. International Journal of Productivity and Performance Management, $59(5), 415-431$

Houtman, I. L. D. (2007). Work-Related Stress. European Foundation For The Improvement Of Living And Working Conditions, 28.

Kamdar, D., \& Dyne, L. V. (2007). The Joint Effects Of Personality And Workplace Social Exchange Relationships In Predicting Task Performance And Citizenship Performance. Journal of Applied Pscyology, 92(5), 1286-1298.

Kassim, Z. A., \& Sulaiman, M. (2011). Market Orientation And Leadership Styles Of Managers in Malaysia. International Journal of Leadership Studies, $6(2), 230-245$. 
Kompier, M. A. J. (2002). Job Design And Well-Being. In M. Schabracq, J. Winnubst, \& C.Cooper (Eds.), Handbook Of Work And Health Psychology,. 429-454. Chichester,England: Wiley

Landsbergis, P.A. (2003). The Changing Organisation Of Work And The Safety And Health Of Working People: A commentary. Journal of Occupational Environmental Medicine, 45(1), 61-72

Lee, H.-C., \& Chuang, T.-H. (2003). The impact Of Leadership Styles On Job Stress And Turnover Intention-Taiwan Insurance Industry As An Example. REFER GROUP ONE.

Limm, H., Gundel, H., Heinmuller, M., Marten-Mittag, B., Nater, U. M., Siegrist, J., \& Angerer, P. (2011). Stress Management Interventions In The Workplace Improve Stress Reactivity: A randomised controlled trial. Occupational Environment Medicine, 68, 126-133.

Martinez, M. C., \& Fischer, F. M. (2009). Stress At Work Among Electric Utility Workers. Industrial Health, 47, 55-63.

McNamara, M., Bohle, P., \& Quinlan, M. (2011). Precarious Employment, Working Hours, Work-Life Conflict And Health In Hotel Work. Applied Ergonomics, 42, 225-232.

McShane, \& Glinow, V. (2010). Organizational Behavior: Emerging Knowledge And Practice For The Real World (5th. Edition). New York: McGraw Hill/Irwin.

Motowidlo, S. J., Borman, W. C., \& Schmit, M. J. (1997). A Theory Of Individual Differences In Task And Contextual Performance. Human Performance, 10, 71-83.

National Institute for Occupational Safety and Health (NIOSH) (2002). The Changing Organisation Of Work And The Safety And Health Of Working People. Cincinatti: NIOSH, Report No. 2002-116. Retreived from http://www.cdc.gov/niosh/02-116pd.html

Oke, A., \& Dawson, P. (2008). Contextualising Workplace Stress: The Experience Of Bank Employees In Nigeria. Paper Presented At the Australian and New Zealand Academy of Management 22nd Annual Conference, Auckland, New Zealand.

Rousseau, V., \& Aube, C. (2010). Team Self-Managing Behaviors And Team Effectiveness: The Moderating Effect Of Task Routineness. Group \& Organization Management, 35(6), 751-781.

Schuldt, B. A., \& Totten, J. W. (2008). An Exploratory Study: Business Faculty And The Faculty Stress Index. Paper presented at the Allied Academies International Conference.

Sekaran, U. (2003). Research Methods for Business: A skill Building Approach (4th ed.). Hoboken, New Jersey: John Wiley \& Sons, Inc.

Stashevsky, S., \& Koslowsky, M. (2006). Leadership Team Cohesiveness And Team Performance. International Journal of Manpower, $27(1), 63-74$.

Taleb, H. M. (2010). Gender and Leadership Styles In Single-Sex Academic Institutions. International Journal of Educational Management, 24(4), 287302.

Wu, T. C., Chen, C. H., \& Li, C. C. (2007). Correlation Among Safety Leadership, Safety Climate And Safety Performance. Journal of Loss Prevention in the Process Industries, 6(3), 261-272.

Yahaya, A., Yahaya, N., Arshad, K., Ismail, J., Jaalam, S., \& Zakariya, Z. (2009). Occupational Stress And Its Effects Towards The Organization Management. Journal of Social Sciences, 5(4), 390-397.

Yukl, G. (2008, April 2008). The Importance Of Flexible Leadership. Paper Presented At The Society For Industrial-Organizational Psychology, San Francisco, CA.

Yun, S., Cox, J., Henry P. Sims, J., \& Salam, S. (2007). Leadership And Teamwork: The Effects Of Leadership And Job Satisfaction On Team Citizenship. International Journal of Leadership 2(3), 171-193. 